\title{
PERFORMANCE IMPROVEMENT MODEL OF HUMAN RESOURCES (HR) THROUGH DIGITAL KNOWLEDGE SHARING
}

\author{
Marisa Giantari"
}

* Affiliation: SMP N 1 Bulu, Rembang, Indonesia

email: mgiantari@gmail.com

\begin{abstract}
:
This research is an explanatory research with a quantitative approach, which aims to test and analyze a research model where Human Capital and Social Capital predicts Human Resource Performance (HR) with Digital Knowledge Sharing as an intervening variable. The population in this study were 206 State Civil Apparatus (ASN) of 4 SKPD in the Rembang Regency Government. There were 102 ASN respondents who filled out and completed the research questionnaire. The collected data is processed using the SEM concept with the SmartPLS 3.0 Program, with the results of the study proving that the Variables of Human Capital, Social Capital and Digital Knowledge Sharing each have a significant positive effect on the Performance of Human Resources (HR), and Digital Knowledge Sharing partially mediates the influence of Social Capital on Human Resource Performance.

Keywords : Human Capital, Social Capital, Digital Knowledge Sharing, and Human Resource Performance (HR)
\end{abstract}

\section{INTRODUCTION}

The acceleration of the flow of globalization, advances in science and technology, has prompted the birth of the Knowledge-based Economy (Knowledge-based Economy). Where Intellectual capital (IC) as an important element in the era of knowledge-based assets have become the focus of attention by many people from different disciplines (Harrison and Sullivan, 2000). According to Helmiatin et al (2016), Intellectual Capital is applied experience, technology, organizational relationships, and skills to create a competitive advantage of the company, so that the role of Intellectual Capital is becoming very influential on the performance of employees that will eventually affect the performance of the organization. Baron et al (2013) States there are three elements of intellectual capital that are human capital, social capital, and organizational capital.

Human capital is a combination of Knowledge, skills, capability, and innovation of a person who applied in the conduct of its work so as to create value for achieving goals. Value-added that is formed will be 
beneficial for the human resource in improving its performance so as to provide sustainable benefits for an organization in the future.

Social Capital contributes to the success of the individual as an employee of the company. Assets contained in it is the quality of its work in performing networking (network), a sense of trust to the environment (trust), and activity to do activities outside their job description that corresponds to the values in the environment. The climate of the organization that successfully built on the basis of trust, confidence, and the similarities that value can help employees in cooperation and make it more easily in an attempt to improve their performance (Ernstmann et al, 2009).

Next performance will achieve optimal results when supported by the knowledge that their application can be used by organizations to influence the quality of service. Thus knowledge management plays an important role in the company (Darroch, 2005). Asrar and Anwar (2016) State that knowledge is an important element for the survival of the Organization in a dynamic and competitive environment today. According to (Ho and Kuo, 2013) of knowledge helps organizations maintain a competitive edge, therefore the organization needs to have a proper policy in managing knowledge (knowledge management).

According to Dalkir (2005), there are 3 elements of implementing knowledge management (1) knowledge creation (knowledge creation), (2) knowledge sharing (knowledge sharing), and (3) the application of knowledge (knowledge application). The organization is not capable of creating knowledge without action and interaction with his officers. This is where the importance of knowledge sharing as one of the methods in the knowledge management to provide an opportunity to employees or organization members in sharing knowledge, experience, and ideas to the employees or other members. Among employees, education, and knowledge sharing very large role to enhance the capabilities of human resources in thinking logically to produce something creative and innovative (Setiarso et al, 2009).

Rapid developing technology and information in today's digital era spawned the trend Information-based knowledge sharing Communication Technology (ICT) we call with the Digital Knowledge Sharing. ICT make knowledge sharing easier and more productive. More and more applications Technology Information (it) specifically created with the purpose of improving the culture of knowledge sharing based virtual (Alamgir and Shahid, 2011). Multimedia features allow users to create content that can be shared so that can give rise to collective intelligence in organizations. For the organization should be able to customize the working environment in which employees get involved in social interactions, sharing of experiences and observations virtually, as well as have informal relations with each other which is based on mutual trust ( Panahi 2012 et al.). ICT is a channel that can be used by employees to perform the activity of knowledge sharing in different variants for example via email, blog, WhatsApp, or other social media (Eze, 2013). The application of digital knowledge sharing was instrumental in the enhancement of the performance of the individual in an organization, because, through knowledge sharing, tacit knowledge as well as explicit knowledge can be deployed, implemented, and expanded (Trivelas et al, 2015).

Some research has proved the existence of a link between Intellectual Capital which includes variable human capital and social capital against the performance of employees in an 
organization, but it's still a little bit of research that uses variables digital knowledge sharing. Amani and Ghomi (2016) to test the influence of components of Intellectual Capital (Human Capital, Capital Structure, and Communicational Capital) against the performance of the employees of oil companies in Iran that the outcome is the third independent variable has a significant positive influence on performance clerk. Similarly, results of research Gezinski LB (2011) and Putiri B Katili (2016) concluded that the human capital and social capital effect positive significantly to the performance of employees. This suggests that the role of human capital and social capital is very important because it can encourage the creation of a climate of excellent service that will support the achievement of a superior performance both individually and the organization. However, a different result is summed up by Helmiatin, et al. (2016), where Human Capital is not a significant effect on performance clerk. Ramanda and Muhtar (2015) also argues that the Human Capital and Social Capital do not affect performance significantly to employees.

Based on the above study and research gap earlier in the research study will test on the influence of human capital and social capital against HR performance by incorporating variable Digital Knowledge Sharing as an intervening variable.

\section{LITERATURE REVIEW}

\section{Human Resources Performance}

Performance can be achieved by a person in carrying out its work in accordance with the standards and criteria that have been set (Rivai, 2005). Ongkorahardjo (2008) state that performance is a result of the work of an accomplished person in carrying out the duties charged to him based on the skills, experience, and the effectiveness of time as measured by considering quality, quantity, and timeliness..

Employee performance is basically a thing that is individual because each employee has a different ability difference associated with human capital and social capital. Someone can work well if in accordance with its capabilities, and supported by the people around him are also its environment. Other words, the necessary alignment of capability to the characteristics of the work will be completed.

Factors that affect directly against the level of attainment of performance of employees according to Ruky in Tangkilisan (2005) one of which is the use of work equipment covering technology and working methods which are used to produce a product and the service, the more qualified technology used, it will be the higher performance of the individual. Likewise, the use of Information Technology (IT) in the environmental organization as a medium in knowledge sharing (Digital Knowledge Sharing) are expected to contribute to the improvement of human resources performance.

According to law No. 5 of the year 2014, article 76 of the performance assessment of civil servants who then stated at PP. 46-year 2011 about the assessment indicators of achievements of the Work of civil servants which consists:

1. Assessment of the Target Work employees (SKP) which includes :

a. Quality of work refers to the thoroughness, skill or creativity, and the precision of the target. 
b. The quantity of work output includes not only a routine task but also extra duties and urged.

c. timeliness in completing the job effectively and efficiently.

d. Costs incurred must correspond to the Budget Plan.

2. The assessment of Work Behavior (PK) which includes:

a. Service Orientation, that is able to complete the tasks of the Ministry with their best with courteous attitude and to satisfy both internal and external services for the organization.

b. Integrity, that in carrying out the task of being honest, sincere, and never abused his authority.

c. Commitment, seeking earnestly carry out its task in Sepik and succeed as well as to give priority to the interests of private interests rather than limited.

d. Discipline means to obey the legislation and regulations limited in force with a sense of responsibility and always obey the provisions of the working hours.

e. cooperation, i.e. being able to collaborate with peers, superiors, subordinates, both within and outside the Organization,

f. leadership, namely the ability to lead, influential, strong person, respected, authoritative and can motivate others.

\section{Human Capital}

Human capital is the potential of the individual as an employee of containing knowledge, experience, skills, attitude, which is used to create added value for the Organization and contribute to improving HR performance (Peterson et al., 2005). Theodore Schultz in Irianto (2009) believes that Human Capital, as well as other resources, need to be invested, that is through education and training that can improve the quality and productivity of employees. Han, et al (2007), indicating human capital is the ability of employees in realizing a prime performance.

Indicators of Human Capital according to The and Lin (2009) is the knowledge, skills, experience, competence, attitude, commitment, and personal characteristics of the individual. While indicators of Human Capital based on Shabarati et al (2010) is the innovation and creation, training and education, experience and expertise.

\section{Social Capital}

Social capital is an asset which is determined by the relationship - social relationships that reflect the unity and mutual trust between the employees who will then create value for easy organization in achieving a common goal (Ghozal, 1998). Putnan (1993) States that social capital is a feature of social organization such as networks, norms, and social trust, that can facilitate coordination and cooperation for the joint benefit of including performance improvement.

Social capital is divided into 3 dimensions (Nahapiet and Ghoshal, 1998)

1. The dimensions of the structural relationship of social interactions, including those used to gain access, information, and resources. 
2. relational Dimension includes aspects that emerged from the onset of interaction that is trust and loyalty.

3. cognitive Dimension includes attributes such as shared norms, codes, and action. Indicators of Social Capital based on Ernstmann et al (2009) is the quality of interaction, networking, sharing information, and exchange ideas, knowledge, and the optimization of the quality of the Network. While indicators of Social Capital based on Putnan (1993) is participating in the group, became part of a group, the attitude of trust, tolerance, the norm.

\section{Digital Knowledge Sharing}

Digital Knowledge Sharing knowledge sharing activities are using the medium of ICT. Agree with Grieve et al (2013) stating that social media technology can be a useful tool to convey the knowledge gained through experience. Majchrzak et al (2013) have examined the application of the function of social media for the purpose of sharing knowledge within the company and the contribution what was able to be given. The first feature is identified meta voicing which gives the name on the user's ability to deliver their opinions directly. Metavoicing involves actions such as comments, love, share, upvote, and others..

Thus, Digital Knowledge sharing can be defined as the activity of sharing knowledge with the use of digital media (ICT) in different variants for example via telephone, SMS, email, blog, or social media, WhatsApp other useful for individuals to enrich the already existing competencies, such as communicating, interpersonal relationships, discussions, the creation of new ideas, creativity, planning, problem-solving, and team working.

Knowledge has two types; implicit and explicit knowledge (Nonaka, 1995). Explicit knowledge refers to knowledge that can be expressed clearly; While the implicit knowledge refers to knowledge that is difficult to pass on to others because it is so personal (Lai, 2013). Knowledge sharing refers to a voluntary behavior by individuals to give access to others to their own knowledge and experience (Cyr and Choo, 2010).

Digital indicators Knowledge Sharing according to Grieve et al (2013) are:

The Internet as a means of collecting information, share knowledge and experiences via social media, interactive technologies and proactive, as well as discuss online.

\section{The Relation Between Human Capital and Digital Knowledge Sharing}

The relevant characteristics of Human capital are education, experience, and knowledge (Writh et al., 1995) are believed to play a role in the management of knowledge management where knowledge management will facilitate the functional behavior employees against the knowledge creation, knowledge sharing (knowledge sharing), and the application of knowledge (Kuo, 2011). In other words, the level of quality of the human capital affects the attitude of voluntary and individual awareness in sharing knowledge via digital with fellow members of the Organization.

\section{The Relation Between Social Capital with Digital Knowledge Sharing}

Social capital became a highly effective catalyst for Digital knowledge-sharing because of social capital can be a source of information (Coleman, 1999). With the existence 
of similarity in attitude, the individual will have more desire to work together and share the knowledge they have. In addition, social capital lowers overall costs of coordination (Chisholm $\&$ Nielsen, 2009). Human resources with the potential of social capital are more likely to initiate coordination in their network, thus increasing the willingness of sharing the knowledge they have.

\section{The Relation Digital Knowledge Sharing with Human Resource Performance}

Digital Knowledge Sharing can only be done when each Member has ample opportunity in delivering opinions, ideas, experiences, and knowledge to other members through social media. Digital Knowledge Sharing can grow and thrive when supported by an appropriate condition. While the condition is determined by three key factors, namely the person, organization and technology (Subagyo, 2007). Next digital knowledge-Sharing activities will assist the individual in obtaining needed information, develop their skills and knowledge so as to be more easily and effectively in completing the work, so that influence on the performance of human resource..

\section{Research Empirical Model}

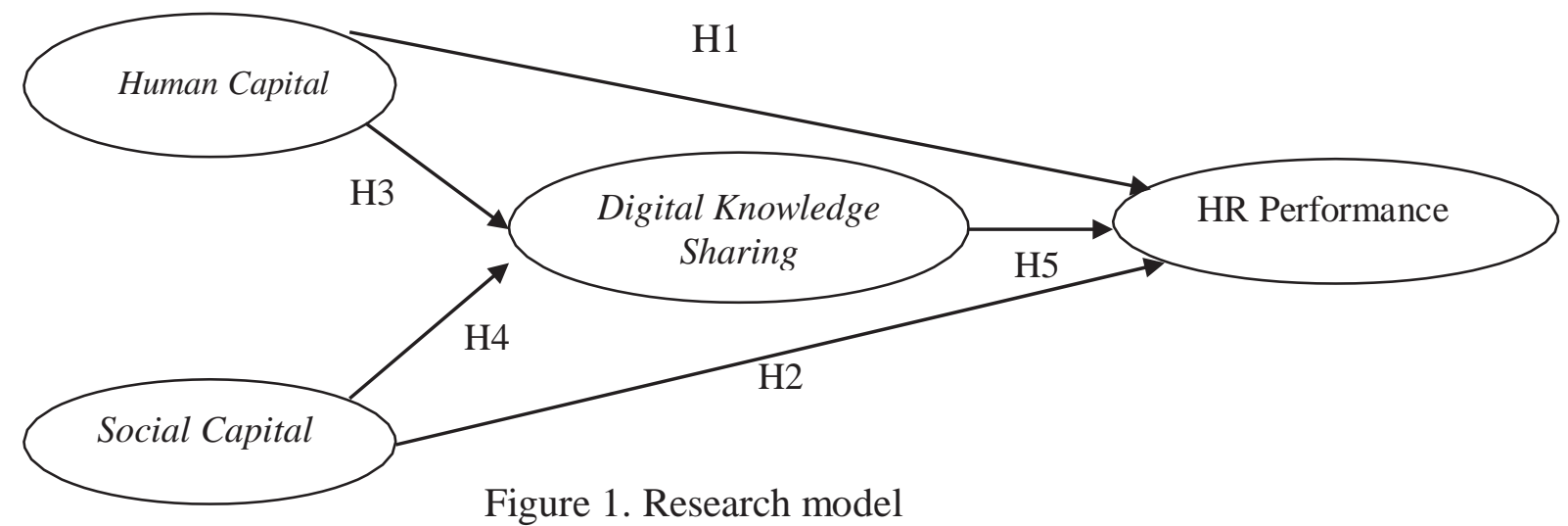

Based on the Foundation of theory and framework of thought above, the hypothesis proposed in this research are as follows:

H1 : when Human Capital is increasing then increasing HR Performance

H2 : when Social Capital is increasing then increasing HR Performance

H3 : when Human Capital increases then the Digital Knowledge-Sharing activity also increased

H4 : If Social Capital has increased then the Digital Knowledge-Sharing activity also increased

H5 : If Digital Knowledge-Sharing Activity is increasing then increasing HR Performance.

\section{METHODS}

This research is explanatory research (explanatory research) that use a quantitative approach. The population in this research is the establishment of Civil Servants of the State (ASN) from the Government in an environment of SEGWAY 4 Rembang totaling as many as 
206 ASN. Sample determination technique using accidental sampling so obtained as much as 102 respondents with data collection using the questionnaire instrument which spread through the Google application form and manually by using the print paper. Data that has been collected is analyzed using the concepts of Structural Equation Models (SEM) with Partial Least Square (PLS) which includes the test validity and reliability as well as the testing of hypotheses (path analysis).

The variables and indicators are as follow:

Table 1. Research variables and indicators

\begin{tabular}{|c|c|c|c|c|}
\hline No & Variable & Operational Definition & Indicator & Source \\
\hline 1. & $\begin{array}{l}\text { ASN } \\
\text { (Y2) } \\
\text { Performance }\end{array}$ & $\begin{array}{l}\text { Achievements or results } \\
\text { achievements task in the } \\
\text { activity or program that has } \\
\text { been planned in order to } \\
\text { achieve the goals and targets } \\
\text { that have been set by an } \\
\text { organization as measured } \\
\text { by considering the quality, } \\
\text { quantity, and timeliness. }\end{array}$ & $\begin{array}{l}\text { 1. Quality } \\
\text { 2. Quantity } \\
\text { 3. Punctual } \\
\text { 4. Service } \\
\text { 5. Cooperation } \\
\text { 6. } \text { Discipline }\end{array}$ & PP 47 Year 2011 \\
\hline 2. & $\begin{array}{l}\text { Human } \\
\text { Capital } \\
\text { (X1) }\end{array}$ & $\begin{array}{l}\text { Individual assets in the } \\
\text { form of knowledge, skills, } \\
\text { innovation and work attitude } \\
\text { that is used to run the task } \\
\text { and create added value } \\
\text { for the sake of achieving } \\
\text { excellent Performance } \\
\text { while contributing to the } \\
\text { Organization in the future. }\end{array}$ & $\begin{array}{l}\text { 1. Education and training } \\
\text { 2. Knowledge } \\
\text { 3. Skills } \\
\text { 4. Attitude } \\
\text { 5. Creation and } \\
\text { Innovation }\end{array}$ & $\begin{array}{l}\text { Shabarati et al } \\
\text { (2010), Yang and } \\
\text { Lin (2009) }\end{array}$ \\
\hline 3. & $\begin{array}{l}\text { Social Capital } \\
\text { (X2) }\end{array}$ & $\begin{array}{l}\text { Social capital is expressed } \\
\text { in the form of similarity of } \\
\text { beliefs and values and social } \\
\text { interaction among members of } \\
\text { the organization that includes } \\
\text { networks, norms, and beliefs. }\end{array}$ & $\begin{array}{l}\text { 1. Interaction } \\
\text { 2. Networking Quality } \\
\text { 3. Trust } \\
\text { 4. Norm }\end{array}$ & $\begin{array}{l}\text { Ernstmann et al } \\
\text { (2009), Putnan } \\
\text { (1993) }\end{array}$ \\
\hline 5. & $\begin{array}{l}\text { Digital } \\
\text { Knowledge } \\
\text { Sharing } \\
\text { (Y2) }\end{array}$ & $\begin{array}{l}\text { knowledge sharing activities } \\
\text { with the use of digital media } \\
\text { (ICT) in different variants for } \\
\text { example via telephone, SMS, } \\
\text { email, blog, WhatsApp or } \\
\text { other social media is helpful } \\
\text { for individuals to enrich the } \\
\text { competencies that already } \\
\text { exist, such as communicate, } \\
\text { interpersonal relationships, } \\
\text { discussions, the creation } \\
\text { of new ideas, creativity, } \\
\text { planning, problem-solving, } \\
\text { and team working. }\end{array}$ & $\begin{array}{l}\text { 1. The Internet as a } \\
\text { means of collecting } \\
\text { information } \\
\text { 2. Share knowledge and } \\
\text { experiences via social } \\
\text { media technologies } \\
\text { 3. Interactive and pro- } \\
\text { active } \\
\text { 4. Online discussion }\end{array}$ & Grieve et al (2013) \\
\hline
\end{tabular}




\section{RESULT AND DISCUSSION \\ Validity Trials}

Test validity is a tool used to measure is valid or whether a questionnaire. Test validity in PLS can use two methods, namely convergent validity, and discriminant validity. Convergent validity can be seen from the outer loading value of each indicator variables. An indicator is said to have good validity if the value of the outer loading above 0.70 , but measuring the value of loading up to 0.50 .6 still considered sufficient for inclusion in the model that is still being developed (Ghozali, 2006). While the Discriminant validity of the values seen AVE where the value $0.5>$ AVE

Table 2. Average Variance Extracted (AVE)

\begin{tabular}{lcl}
\hline & $\begin{array}{c}\text { Average Variance } \\
\text { Extracted }(\boldsymbol{A} \text { VE })\end{array}$ & Note \\
\hline Digital Knowledge Sharing & 0,589 & Valid \\
\hline Human Capital & 0,509 & Valid \\
\hline HR Performance & 0,596 & Valid \\
\hline Social Capital & 0,578 & Valid \\
\hline
\end{tabular}

Source : processed data, 2018

\section{Reliability Trials}

Reliability test is done by looking at the value of the composite reliability and Cronbach's Alpha block of indicators that measure invalid constructs. The results of the Alpha compositing reliability and Cronbach's will show a satisfactory result if the value above 0.7 .

Table 3. Composite Reliability

\begin{tabular}{|l|c|c|c}
\hline & $\begin{array}{c}\text { Composite } \\
\text { Reliability }\end{array}$ & $\begin{array}{c}\text { Cronbach's } \\
\text { Alpha } \\
\text { V AVE }\end{array}$ & Note \\
\hline Digital Knowledge Sharing & 0,851 & 0,773 & Reliabel \\
\hline Human Capital & 0,837 & 0,759 & Reliabel \\
\hline HR Performance & 0,896 & 0,858 & Reliabel \\
\hline Social Capital & 0,845 & 0,758 & Reliabel \\
\hline
\end{tabular}

Source : processed data, 2018 


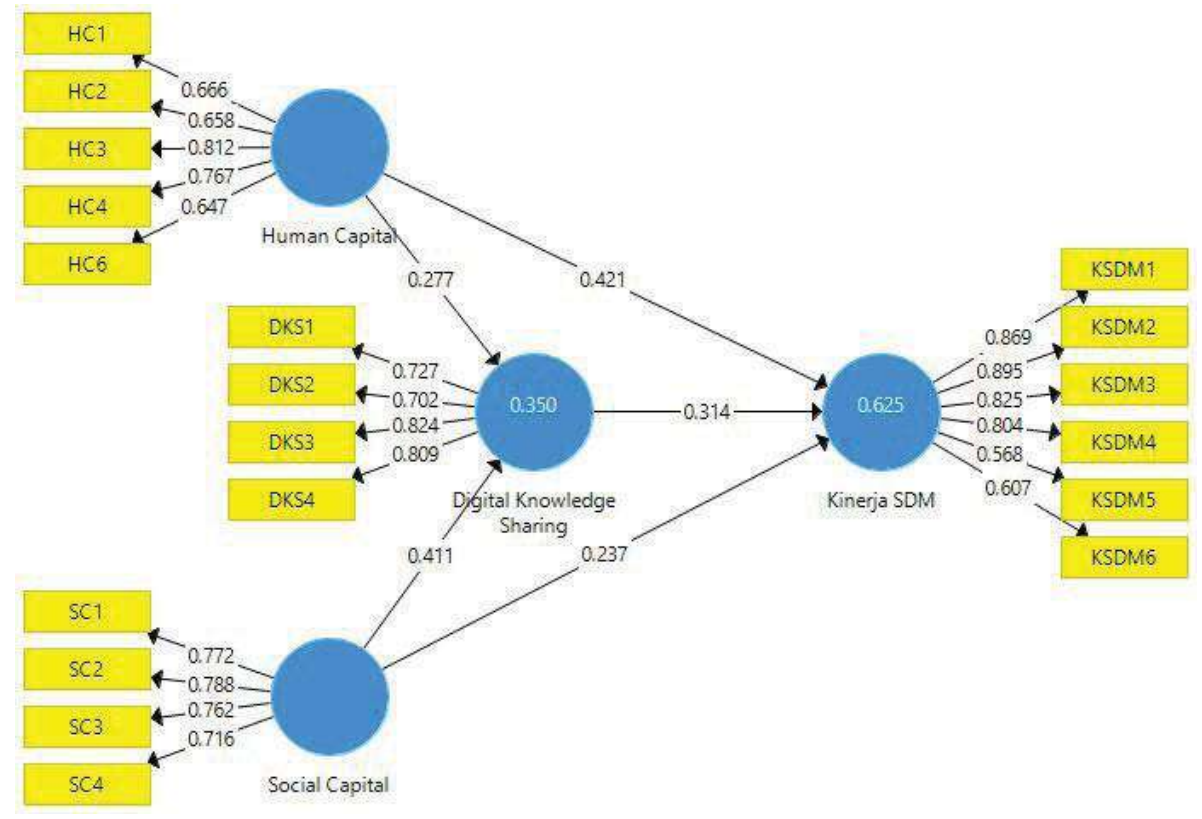

Figure 1 Output Outer model

\section{Inner Model Trials (Structural Model)}

The inner model test is done to test the relationship between endogenous and exogenous invalid constructs that have been previously hypothesized. Some test in inner models, namely: Value $\mathrm{R}^{2}$ and estimation of the coefficient of the line (test Hypothesis). Inner models describe the relationship between latent variables based on obtaining the results output from the model structure of the loading factor of invalid constructs a graph of the relationship between the variables of Human Capital, Social Capital, Digital Knowledge Sharing, and performance of human resources.

Table 4. R-Square

\begin{tabular}{|l|r|r|}
\hline & $\boldsymbol{R}$ Square & $\boldsymbol{R}$ Square Adjusted \\
\hline Digital Knowledge Sharing & 0,350 & 0,337 \\
\hline HR Performance & 0,625 & 0,614 \\
\hline
\end{tabular}

Source : processed data, 2018

Based On The Table. 4 shows the R-Square value invalid constructs Digital Knowledge Sharing of 0350 which means that the Human Capital and Social Capital was able to explain the variance of the Digital Knowledge Sharing of 35\% and the rest (65\%) affected by other factors which are not examined in this research. Next R-Square is also found in the human resources Performance of 0.625 invalid constructs which means Human Capital, Social Capital, and Digital Knowledge Sharing was able to explain the variance of human resource performance of $62.5 \%(37.5 \%)$ and the rest affected by other factors which are not examined in this research. 
Table 5. Path Coefficient

\begin{tabular}{|l|r|r|r|r|}
\hline & $\begin{array}{c}\text { Original } \\
\text { Sample }\end{array}$ & $\begin{array}{c}\text { Standard } \\
\text { Deviation }\end{array}$ & T Statistics & P Values \\
\hline Digital Knowledge Sharing -> HR Performance & 0,314 & 0,101 & 3,108 & 0,001 \\
\hline Human Capital -> Digital Knowledge Sharing & 0,277 & 0,149 & 1,863 & 0,032 \\
\hline Human Capital -> HR Performance & 0,421 & 0,074 & 5,664 & 0,000 \\
\hline Social Capital -> Digital Knowledge Sharing & 0,411 & 0,133 & 3,088 & 0,001 \\
\hline Social Capital -> HR Performance & 0,237 & 0,108 & 2,206 & 0,014 \\
\hline
\end{tabular}

Source : processed data, 2018

Based On The Table. 5, the value of the estimated coefficients of the line between invalid constructs must have a significant value. With regard to determining a hypothesis accepted or rejected, then performed by comparing between statistic and table on the condition that if statistics $>$ table (1.66) at the level of significance $(\alpha=5 \%)$ then the hypothesis is accepted.

\section{the influence of Human capital toward Hr Performance}

In table 4 show that Human Capital is a significant positive effect on the performance of human resources due to the larger statistic value table (5,664 statistic > table 1.66) at 5\% significance level $(0.05<0.000)$, and human capital is able to affect the performance of human resources amounting to $42.1 \%$. Thus the hypothesis that the first proposed in this research is accepted..

Human Capital expressed as basic Intellectual Capital refers to factors such as knowledge, skills, and attitudes of employees that result in improved performance, more customers, and increased income for Organization (Chen et al, 2004). Human Capital encourages employees to better educated and skilled, knowledge and experience also plays an important role in the ability to create optimal performance. The results of this study are in line with studies conducted by Amani and Ghomi (2016), and Putiri B Katili (2016). Stating that the Human Capital effect significantly to the performance of the Employee.

\section{the influence of Social capital toward Hr Performance}

Table 5 shows that Social Capital effect positive significantly to the performance of human resources with proven value (2,206 statistics $>$ table 1.66$)$ at $5 \%$ significance level $(0.05$ $<0.014$ ), and social capital are able to affect the performance of human resources amounting to $23.7 \%$. Thus the second Hypothesis put forward in this study was received.

The results showed that the accumulation of social capital effectively is an important element in the effort improved overall performance, both individually and the organization. Social capital can not only link the mutual trust in the Organization but also able to affect individual decisions to start the work, sharing knowledge and information, as well as the strengthening of the network of organizations, which in the end lead to improved performance for better HR. 
The results of this study confirmed the results of the research carried out by Amini and Gomi (2016), LB Gezinski (2011) and Putiri (2016) that proves that Social Capital provides a significant positive influence on the performance of employees..

\section{the influence of Human capital toward digital Knowledge Sharing}

Based On The Table. 5 Note that the beta coefficient 0.227. This suggests that the influence of Human Capital against digital Knowledge Sharing amounting to $22.7 \%$ with significant values of $0.032<0.05$ and value $(1,863$ statistic $>$ table 1.66$)$. Thus the third Hypothesis put forward in this study are accepted.

Level of quality human capital affects the attitude of voluntary and individual awareness in sharing knowledge via digital with fellow members of the organization. Next digital knowledge-Sharing activities will assist the individual in obtaining needed information, develop their skills and knowledge so that it will be more easy and effective in finishing the job. Thus if human capital increases then the digital knowledge sharing activities also increased. The same research results conducted by Obeidat, et al,. (2017) stating that the human capital effect of digital activity significantly to Knowledge Sharing.

\section{the influence of Social capital toward digital Knowledge Sharing}

Based On The Table. 5 Note that the beta coefficient 0.411 . This suggests that the influence of Social Capital on Knowledge Sharing of digital against $41.1 \%$ with significant value of $0.001<0.05$ and value $(3,088$ statistic $>$ table 1.66). Thus the fourth Hypothesis proposed in this study are accepted.

Social capital tends to increase the number of information sources and a willingness to share knowledge in social Web, thus enhancing the knowledge, skills, and abilities required for the job. It can be concluded that social capital can improve the performance of the working group by increasing knowledge together in a working group. The results of this study are in line with research Athoilah (2017) and Mura (2012) who explains that social capital effect significantly to digital knowledge sharing.

\section{the influence of Digital Knowledge Sharing toward HR Performance}

Based On The Table. 5 Note that the beta coefficient 0.314. This suggests that the influence of the digital Knowledge Sharing on a performance of human resources amounting to $31.4 \%$ with a significant value of $0.001<0.05$ and value $(3,108$ statistics $>$ table 1.66$)$. Thus the fourth Hypothesis proposed in this research is accepted..

Digital Knowledge sharing activities include sharing of experience and knowledge will assist individuals in resolving the difficulties individuals - trouble work based on experience, as well as the sharing of knowledge which will provide contributions for individuals to improve the effectiveness and efficiency of the process of the work. Thus increasing the Digital Knowledge-sharing activities will improve the performance of individuals. The results of the same study supported by Aulia (2016) and Athoilah (2017) which concluded that Knowledge Sharing effect significantly to the performance of human resources. 


\section{Indirect effect of Human Capital and Social Capital against the performance of Human Resources through the Digital Knowledge Sharing}

Table 6. Analysis of direct effect and Indirect Effect

\begin{tabular}{|l|c|c|c|}
\hline & $\begin{array}{c}\text { Direct } \\
\text { Effect } \\
\text { Result }\end{array}$ & $\begin{array}{c}\text { Indirect } \\
\text { Effect } \\
\text { Result }\end{array}$ & $\begin{array}{c}\text { Total of direct } \\
\text { and indirect } \\
\text { effect }\end{array}$ \\
\hline Digital Knowledge Sharing -> HR Performance & 0,314 & -- & -- \\
\hline Human Capital -> Digital Knowledge Sharing & 0,277 & -- & -- \\
\hline Human Capital -> HR Performance & 0,421 & 0,087 & 0,508 \\
\hline Social Capital -> Digital Knowledge Sharing & 0,411 & -- & -- \\
\hline Social Capital -> HR Performance & 0,237 & 0,129 & 0,366 \\
\hline
\end{tabular}

Source : processed data, 2018

Table 7. Indirect Effect

\begin{tabular}{|l|r|r|r|r|}
\hline & $\begin{array}{c}\text { Original } \\
\text { Sample }(O)\end{array}$ & (STDEV) & $\begin{array}{c}T \\
\text { Statistics }\end{array}$ & P Values \\
\hline $\begin{array}{l}\text { Human Capital -> Digital Knowledge } \\
\text { Sharing-> HR Performance } \\
\begin{array}{l}\text { Social Capital -> Digital Knowledge } \\
\text { Sharing-> HR Performance }\end{array}\end{array}$ & 0,087 & 0,069 & 1,267 & 0,103 \\
\hline
\end{tabular}

Source : processed data, 2018

Based on the test results the path presented, on table 7 and table 8, note that influence directly (direct effect) of human capital on a performance of HUMAN RESOURCES is of 0,421 . The calculation of the Indirect effect is done by multiplying the beta coefficient of the two structural formula i.e. $\mathrm{bY}_{11}$ and $\mathrm{b} \mathrm{X} \mathrm{Y} \mathrm{Y}_{21}$ with beta coefficient respectively 0.277 and 0.314 so indirect effects is obtained from human capital HR on the performance of 0.087 and the total direct and indirect influence of 0.508 . It can be concluded that the indirect effect of human capital on the performance of human resources through the Digital Knowledge sharing is able to describe of $8.7 \%$. However, no effect was significant, as evidenced by the value of the sig $0.103>0.05$. Thus the variable Digital Knowledge sharing is not able to mediate the influence of human capital on the performance of human resources.

This is due to the character and attitude of each individual to share knowledge that is both explicit and tacit knowledge, also supported by the ASN in Rembang District environment that have not been familiar with the culture of knowledge sharing through digital media. They still feel more comfortable doing the activity of sharing knowledge with conventional way i.e. face to face directly. Moreover, the lack of support facilities in the management of digital-based knowledge management in the work environment causing employee performance improvement efforts based on human capital through digital knowledge sharing is not reached.

While the direct influence (direct effect) from social capital against the performance of human resources was of 0.237 . The calculation of the Indirect effect is done by multiplying the 
beta coefficient of the two structural formula i.e. bY ${ }_{12}$ and $\mathrm{X}$ by $\mathrm{Y}_{2}{ }_{1}$ with beta coefficient respectively 0.411 and 0.314 so indirect effects is obtained from human capital against the performance of HUMAN RESOURCES 0.129, and total direct and indirect influence of 0.366 . It can be concluded that the indirect effect of social capital on the performance of HUMAN RESOURCES through the Digital Knowledge sharing is capable of $12.9 \%$ explained. But still influential, as evidenced by the significant value of sig $0.000<0.05$. Thus the variable Digital Knowledge sharing was able to mediate the influence of social capital on the performance of human resources partially.

These results prove that Social Capital to form a sense of community in interaction, trust, solidarity, and the responsibility will be shared so that the progress of the Digital Knowledgesharing activities with more social capital-based giving a contribution to the improvement of the performance of human resources.

\section{CONCLUSION}

In general, the study concluded that performance in HUMAN RESOURCES can be strengthened and enhanced through Human Capital, Social Capital, and Digital knowledge Sharing. Based on testing the hypothesis put forward by using Structural Equation Modeling (SEM) software-based SmartPLS 3, then it can be summed up as follows:

1. Human capital can improve significantly the performance of human resources. It means to optimize the performance of HR management then need to apply the principle of the right man on the right place, i.e. putting a job in the field of human resources in accordance with the educational background and expertise. Encouraged to attend training that will enhance their skills and increase their knowledge so that human resources are expected to be able to find creative ideas in the completion of the work and improve performance.

2. Social capital can improve significantly the performance of human resources. It means to optimize the performance of HR management then needs to maintain positive interaction between employees through the culture of smile, greeting, so it strengthens the community, of trust and shared responsibility in improving the performance of human resources or organizational performance.

3. Human capital effect significantly to Digital Knowledge Sharing. It means to increase the digital knowledge sharing activities, the management has to improve the quality of education, knowledge, and experience of human resources as well as encouraging voluntary attitude and awareness for knowledge sharing via digital with fellow Member organizations.

4. Social capital effect significantly to Knowledge Digital Sharing. Where if social capital in organizations is increasing, it will be increasingly formed a sense of community in interaction, trust, and tolerance so as to improve the attitude willing to help each other and share information is also the knowledge that they have Although through digital media (Digital Knowledge Sharing).

5. Digital knowledge sharing effect significantly to the performance of human resources. This means that the Performance can be enhanced through HR management facility digital knowledge sharing activities would like to hold a discussion forum on a regular basis related to current information and knowledge via WhatsApp renewable group. 
6. digital Variables knowledge sharing is able to mediate between the influence of social capital on the performance of human resources partially but hasn't been able to mediate the influence of human capital on the performance of human resources. This is due to the presence of more value in the social capital that includes a sense of interaction in the community, solidarity, and shared responsibility in achieving the goal of causing the digital knowledge sharing activities to become more instrumental in HR Performance improvement efforts.

\section{REFERENCES}

Alamgir SS. 2011. A relational study on service climate, supportive management, work efffort, job satisfaction and employee service quality in the context of real estate sector of Bangladesh. J International Review of Bussiness Research Papers 7 (2)

Amani, T. Ghomi, Zhinat. (2016). The Relationship between Intellectual Capital and Organizational Learning on Performance of National Iranian Oil Refining and Distribution Company Employees. International Research Journal of Managemen Sciences Vol. 4 (3): 202-205

Asrar-ul-Haq, M. and Anwar, S. (2016). A Systematic Review of Knowledge Management and Knowledge Sharing: Trends, Issues, and Challenges. Cognet Business and Management : $3,1-17$

Athoilah. (2017). Model Peningkatan Knowledge Sharing Berbasis Modal Sosial dan Learning Organization Terhadap Kinerja Agency pada PT. Prudential Life Assurance: Ekobiss: Vol.18 (2), 174-183

Aulia, Astuti.2016. Pengaruh Budaya Organisasi Terhadap Kinerja Karyawan melalui Knowledge sharing sebagai Variabel Intervening (Studi pada PT. Pelabuhan Indonesia III Cabang Tanjung Perak Surabaya). Jurnal Ilmu Manajemen. 4 (3) : 1-15

Balkar. (2015). The Relationship between Organizational Climate, Innovative Behavior and Job Performance of Teacher. International Online Journal On Educational Sciences.

Baron, Angela \& Armstrong, Michael. (2013). Human Capital Management. Jakarta: Penerbit PPM.

Chen, J., Zhu, Z., Xie, H. Y.(2004). Measuring intellectual capital: A new model and empirical study. Journal of Intellectual Capital, 5(1), 195-212

Coleman, D., 1999, Groupware: collaboration and knowledge sharing. Knowledge Management Handbook, CRC Press, Boca Raton, FL, pp. 12-15.

Cyr, S. and Choo, C.W. (2010). The Individual and Social Dynamics of Knowledge Sharing: An Exploratory Study. Journal of Documentation, 66, 824-846.

Dalkir, Kimiz. (2005). Knowledge Management In Theory and Practice. United States of America: Elsevier, Inc. 
Darroch, Jenny. (2005). Knowledge management, innovation and firm performance. Journal of Knowledge Management. 9(3): 101-115.

Ernsmann, N et al. (2009). Social capital and risk management in nursing. J Nurs Care Qual, 24(4): 340-347.

Eze, Nwosu. Harrison, Okafor. (2013). Financial Management in Local Government : The Nigeria Eksperience. International Journal Research. Vol. 4 No.4

Gezinski, L Blair. (2011). Mediating Impact of Social Capital and Human Capital on Employment Outcome among Single Women Who Use Welfare: A Structural Equation Model. Disertation The Ohio State University

Ghozali, Imam. (2006). Structural Equation Modeling, Metode Alternatif dengan Partial Least Square.Semarang: Badan Penerbit Universitas Diponegoro.

Grieve R, Indian M, Witteveen K, Anne TG, Marrington J. (2013), "Face-to-Face of Facebook: Can social Connectedness be derived online?", Computers in Human Behavior, 2013, Vol.29(3), pp.604-609

Han, B. M., Anantatmula, V. S., 2007. Knowledge sharing in large IT organizations: A case study. The journal of information and knowledge management systems , Emerald Group of Publishing Limited 37 (4), pp. 421-439.

Harrison, S. and P.H. Sullivan. (2000). Profitting form intellectual capital; Learning from leading companies. Journal of Intellectual Capital. Vol. 1 No.1.pp.33-46.

Helmiatin, Olivia I, Irman wati, (2016). The Influence of Intellectual Capital on the Performance of Employees. Proceeding of the First American Academic Research Conference on Global Business, Economics, Finance and Social Sciences (AAR16 New York Conference)

Ho, L. and Kuo, T. (2013). How System Quality and Incentive Affect Knowledge Sharing. Industrial Management \& Data Systems ,113, 1048-1063.

Jogiyanto, H,M. Dan Abdillah, Willy. (2014).Konsep dan Aplikasi PLS (Partial Least Square) untuk penelitian empiris. BPFE Universitas Gajah Mada.

Katili, Putiri. B. Pertiwi, D,dan Anggraeni, A. K. (2013). Analisa Hubungan Intellectual Capital Terhadap Business Performance Pada Industri Manufaktur. Universitas Sultan Ageng Tirtayasa.

Lai, W. (2013) Interoperability of Implicit and Explicit Firm-Level Knowledge Accumulation . Journal of Strategy and Management ,6, 229-241.

Lumbantobing, Paul. (2011). Manajemen Knowledge Sharing Berbasis Komunitas. Bandung: Knowledge Management Society Indonesia.

Majchrzak, Ann., Faraj, Samer., Kane, Gerald.,Azad, Bijan. (2013). The Contradictory Influence of Social Media Affordances on Online Communal Knowledge Sharing. Journal of Computer. Vol. 19, Issue 1 
Nahapiet, J and Ghoshal, S. (1998). Social capital, intellectual capital, and the organizational advantage. The Academy of Management Review, 23(2): 242-266.

Nonaka, Ikujiro and Takeuchi, Hirotaka (1995). The Knowledge-Creating Company: How Japanase Companies Create the Dynamic of Innovation. Oxford: Oxford University Press

Ongkorahardjo, M., Susanto, A. \& Rachmawati, D. (2008) Analisis Pengaruh Human Capital Terhadap Kinerja Perusahaan: Studi Empiris pada Kantor Publik di Indonesia. Jurnal Akuntansi dan Keuangan, 10 (1) hlm. 11-21.

Obeidat, et al. (2017). The Effect of Intellectual Capital on Organizational Performance : The mediating Role Of Knowledge Sharing. Communication and network, 9, 1-27

Panahi S, Watson J, Partridge H, (2012), "Social Media and Tacit Knowledge Sharing: Developing a Conceptual Model”, World Academy of Science, Engineering and Technology, World Academy of Science, Engineering and Technology (WASET), Paris, France, pp. 1095-1102

Peraturan Pemerintah Nomor 46 Tahun 2011 tentang indikator Penilaian Prestasi Kerja PNS

Peterson, Suzanne, J \& Spiker, Barry K. (2005). Establishing the Positive Contributory Value of Older Workers: A Positive Psychology Perspective. Journal of Organizational Dynamics, Vol. 34, No. 2, pp. 153-167.

Putnam, Robert D. (1993). The Prosperous Community: Sosial Capital and Public Life. The American Prospect No. 13 Spring.

Ramanda, Y. \& Muchtar, B. (2015). Pengaruh Human Capital dan Organizational Capital Terhadap Kinerja Pegawai: Studi pada Badan Ketahanan Pangan Provinsi Sumatera Barat.UniversitasNegri Padang

Rivai, Veithzal. (2005). Kepemimpinan dan Perilaku Organisasi. Jakarta: PT. Raja Grafindo Persada.

Setiarso, Bambang., et.al (2008). Penerapan Knowledge Manajemen Pada Organisasi. Yogyakarta : Graha Ilmu.

Sharabati, A.A., S.N. Jawad dan Bontis. (2010). Intellectual Capital and Business Performance in the Pharmaceutical Sector of JORDAN. Journal Management Decision. (48)1: 105131.

Tangkilisan, H. N. (2005). Manajemen Publik. Jakarta: Gramedia

Tobing, Paul L. (2007). Knowledge Management : Konsep, Arsitektur dan Implementasi. Yogyakarta : Graha Ilmu.

Trivellas, P., Akrivouli, Z., Tsifora, E., Tsoutsa, P. (2015). The Impact of Knowledge Sharing Culture on job Satisfaction in Accounting Firm with Mediating Effect of general Competencies. E-journal Procedia Economic and Finance Elsevier. 19: 238-247 
Undang - Undang Republik Indonesia Nomor 5 Tahun 2014 tentang Aparatur Sipil Negara.

Widiyanto. (2016). Pedoman Penulisan Proposal dan Tesis. Fakultas Ekonomi Universitas Islam Sultan Agung Semarang

Wright, P. M., \& McMahan, G. C. (2011) Exploring human capital: Putting “Human” back into strategic human resource management. Human Resource Management Journal, $21(2), 93104$

Yang, C., and Lin, C. (2009). Does intellectual capital mediate the relationship between HRM and organizational performance? Perspective of a healthcare industry in Taiwan. The International Journal of Human Resource Management, Vol. 20, No. 9, 1965-1984. 